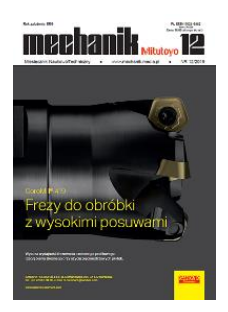

How to cite this article:

Authors: Michał Wieczorowski, Paweł Pawlus, Bartosz Gapiński

Title of article: „Perspectives of modern metrology”

Mechanik, No. 12 (2019)

DOI: https://doi.org/10.17814/mechanik.2019.12.106

\title{
Perspectives of modern metrology
}

\author{
MICHAŁ WIECZOROWSKI \\ PAWEL PAWLUS \\ BARTOSZ GAPIŃSKI *
}

Prof. dr hab. inż. Michał Wieczorowski, michal.wieczorowski@put.poznan.pl, https://orcid.org/0000-0001-7526-8368 - Zakład Metrologii i Systemów Pomiarowych, Instytut Technologii Mechanicznej, Politechnika Poznańska, Poznań, Polska

Prof. dr hab. inż. Paweł Pawlus, ppawlus@prz.rzeszow.pl, https://orcid.org/0000-0002-5630-5300 - Katedra Technologii Maszyn i Inżynierii Produkcji, Politechnika Rzeszowska, Rzeszów, Polska

Dr inż. Bartosz Gapiński, bartosz.gapinski@put.poznan.pl, https://orcid.org/0000-0003-0206-1942 - Zakład Metrologii i Systemów Pomiarowych, Instytut Technologii Mechanicznej, Politechnika Poznańska, Poznań, Polska

The most up-to-date trends in development of length and angle metrology were presented. This development falls within a concept of Industry 4.0 and is understood as Metrology 4.0. Basic elements of these concepts and their connections were shown during years in relation to consecutive industrial revolutions. Specific issues regarding additive technologies were described with a view to functional filtration. Achievements of coordinate measuring technique in macro scale were also presented including optical scanning and computed tomography. In conclusions standardization works regarding the mentioned topics were described.

KEYWORDS: Industry 4.0, measurements, additive technologies, coordinate measuring technique, standardization

\section{Introduction}

Length and angle metrology has been undergoing an intensive development for many years. This is due to many important reasons, among which are new applications of physical principles, automation and development of computer techniques, Industry 4.0 strategy and new production methods - especially incremental ones. All these factors have contributed to the emergence of new measuring instruments on one hand, and changed approach to measuring algorithms and practice on the other. There is often synergy between these factors, which means that e.g. the principles of physics on the basis of which instruments are constructed, combined with better resolution of detectors and better parameters of computational units, allow for the creation of instruments with new possibilities. Automation and robotization force the construction of measuring systems with elements resistant to collisions [1]. At the same time - in line with the spirit of Industry 4.0 and Metrology 4.0 - the use of augmented or virtual reality and artificial intelligence is becoming increasingly important, especially in decision-making processes.

Industry 4.0 can be understood as a multidimensional concept using a package of technologies enabling the creation of autonomous and intelligent production systems capable of self-configuration and self-control, and even self-repair [2]. This allows to increase the efficiency and flexibility of production.

The idea of Industry 4.0 was initiated in Germany - as Industrie 4.0 - in 2011. It was to show what the revolutionization of the organization of global value chains will look like. By preparing the conditions for the functioning of intelligent factories, the fourth industrial revolution creates the world, in which virtual and physical production systems cooperate globally and flexibly. This enables products to be customized and creates new operational models [3].

The main goal of Industry 4.0 strategy is to create the so-called Smart Factory, i.e. an intelligent factory with very high degree of automation and robotization, which implements processes in an optimal way (or very close to it) and in which one can quickly and flexibly change the manufactured products in a customer-oriented way. 
In everyday life, this is supposed to translate into intelligent products, buildings, transport systems, cities and social systems.

As part of Industry 4.0, innovative solutions are created that enable the integration of existing systems equipped with automatic systems, as well as automation and robotization of processes (manufacturing, logistics, etc.) implemented so far using manual systems. This, in turn, forces the development of sensorics towards development of new modules and systems necessary to obtain information about the state of processes and their individual elements. In the further processing, this information is used for multi-criteria process optimization and more efficient use of the resources of the entity performing production tasks. Due to such solutions, machines and technological devices are maintained in efficiency and ready for quick configuration change (reconfiguration). From a technological point of view, basic elements of Industry 4.0 include the Internet of Things technology (consisting in providing network access to individual devices, systems and their operational components configured as a subsystem - clearly identifiable) and the use of artificial intelligence (enabling, among others, quick decision making based on data and premises from a knowledge base created and developed on the basis of daily tasks - neural networks, fuzzy logic, etc.).

\section{Concept of Metrology 4.0}

Measurement plays an important role in Industry 4.0 strategy - based on its results, decisions related to the functioning of systems and their components are made. This in turn translates into the concept of Metrology 4.0 [4].

Such coexistence of metrology with industry, or more broadly with production, has been happening since the dawn of time. Already in ancient times, length and angle measurements played an important role. Strict dimensional requirements were observed when erecting the Egyptian pyramids. Nearly 4,600-year-old Cheops Pyramid, built of approximately 2,300,000 stone blocks with an average weight of over 2,000 kg, was placed on an artificially leveled area in such a way that the height difference of the opposite corners is $13 \mathrm{~mm}$, and the sides of the square base are set relative to the sides of the world with an uncertainty of 4 arc minutes. A drawing was found in one of the ancient tombs, which can be considered as the first documenting application of metrology in production (Fig. 1).

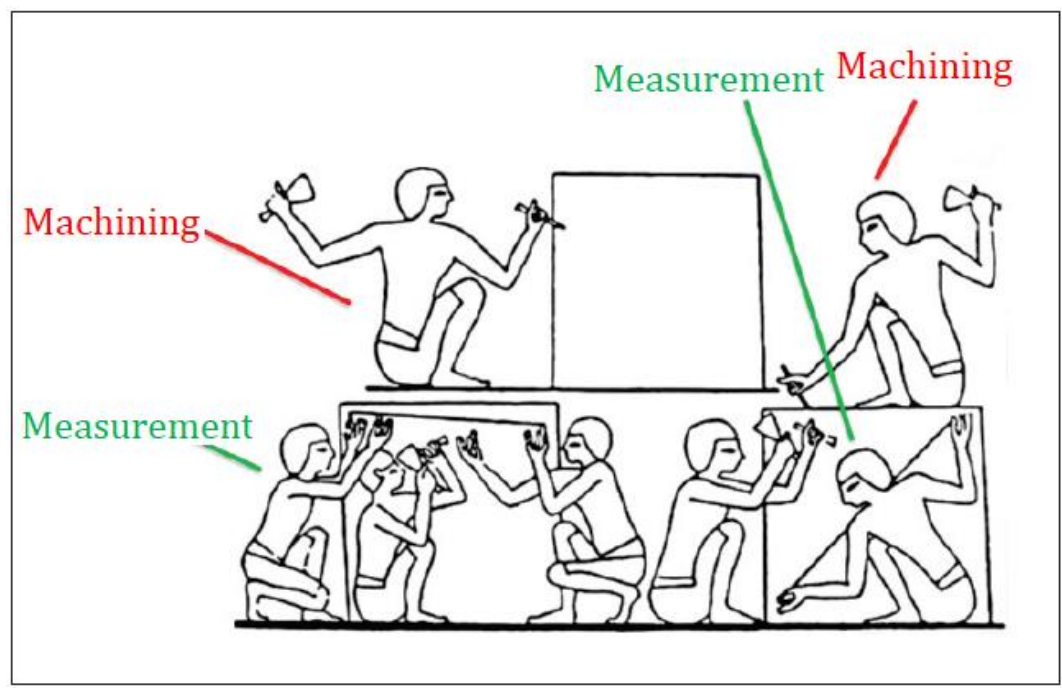

Fig. 1. Metrology in progress from ancient Egyptians' point of view

This drawing shows a classic example of control during production, because rock block machining is carried out simultaneously with its measurements. It follows that the idea of active control arose a long time ago. The control was carried out using length standards that were compared with a higher order standard. The patterns used by the employees were wooden, and the higher order was made of black granite. It was carefully stored and used for comparison with utility models. Thus, in ancient times, there was a hierarchy of patterns, observance of which was an important element of executive work.

During the industrial revolution, metrology was associated with changes in production. When the first mechanical loom was created at the end of the 18th century, and later steam machines - considered today as the markers of the first industrial revolution - also appeared the first vernier caliper. At that time, the French National Assembly adopted a resolution defining the meter as a ten-millionth part of a quarter of the meridian. 
It became the basis for comparing patterns in modern times. The consequence of this was also the final archival meter model.

Less than 100 years later, the second industrial revolution initiated mass production, assembly lines and the dissemination of electricity. Metrology in version 2.0 responded to this by creating a more accurate meter pattern, based on the borders, and standard plates and the entire philosophy of their use by Carl Edvard Johansson (they have been used in industry continuously since 1911). A little later, the first instruments for measuring the surface roughness were developed [5].

The next, third industrial revolution - determinant of which in 1969 became the first PLC controller, and automation, computers and the rapid development of electronics - could already benefit from the redefinition of the meter from 1960. For the first time, the material pattern was replaced by a wave pattern, based on the wavelength of light emitted by krypton ${ }^{86}$ (in 1983, the $17^{\text {th }}$ General Conference of Measures adopted the current definition of meter as the length of the path traveled in vacuo by light during 1/299 $792458 \mathrm{~s}$ ). The end of the 1950 s is also the first coordinate measuring machine (Fig. 2), subsequent versions of which in various construction systems began to appear in the following years.

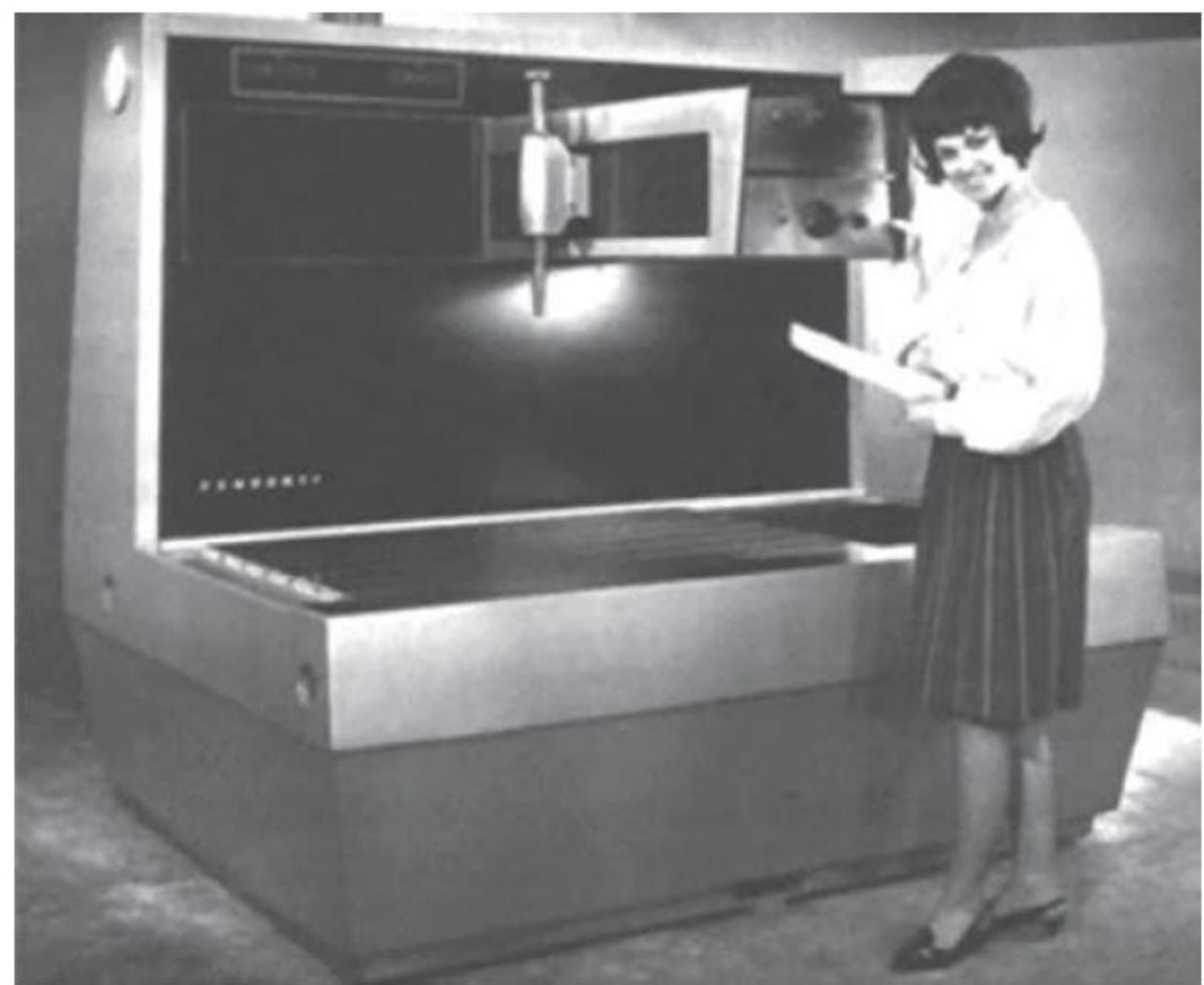

Fig. 2. One of the first examples of a coordinate measuring machine [6]

Metrology 3.0 is further automation of measurements, minimization of errors of measuring devices and new ideas, which in the 70s found expression in the design of the CMM switching head, scanning measurements and the beginnings of surface topography analysis.

Metrology has also played an important role since the beginning of the concept of Industry 4.0. Furthermore, we can safely say that it forced some of its elements. Thus, when 2011 brought the beginnings of current fourth industrial revolution, measurement techniques have already benefited from the development of scanning (including by means of electromagnetic waves) and associated large data sets, as well as digitization and work on colorful deviation maps, which are increasingly widespread. Free surfaces were commonly analyzed, replacing the mathematical description with a point cloud. Other trends in Metrology 4.0 include the use of multisensory and multi-scale analysis, as well as metrology in additive techniques, advanced filtration techniques, collaborative robots, information-rich metrology and as close to production as possible (in the production process).

Metrology 4.0 will affect many elements, and their development will be dictated by its requirements. First of all, the need to verify the status of various devices will contribute to the construction of new sensors. Their operation is associated with the analysis of the state of elements, sub-assemblies of machines and technological devices in order to determine precisely and - what is important - a priori the need for maintenance or repair 
works. Due to this, costly interruptions in the operation of manufacturing systems are eliminated, and - in some industrial plants - the tendency to multiply machines and maintain high spare parts is eliminated. The developing 3D printing technique will allow the production of spare parts on an ongoing basis. The systems will perform repair functions, due to which - in a futuristic vision - the system will diagnose a defective element, order its manufacture and replace it itself. Artificial intelligence (AI) in measuring devices after determining the functional premises of a measuring task or object will select the best conditions for a given application (e.g. sample density, nesting index and filter). It will also allow to specify the measurement strategy (scanning or spot sampling, data collection order or measurement of elements, angles and positions, from which the scanner will collect data, etc.). Finally, it will select the measuring tip or lens, optimal from the point of view of cost criteria and necessary values of accuracy parameters.

An element of this is further automation and robotization, which are already advanced in measuring devices (CNC work of coordinate measuring machines, profilometers, devices for measuring shape errors, etc.). Robotization will cover not only functioning scanning (also optical) systems, but also logistics systems related to the delivery of the object to the measuring space and its transfer to subsequent positions. Camera systems tracking the measurement process will be an additional option. Combined with flexible software, they will allow even a physically distant user to intervene in the measurement process, select features and terminate the measurement process in a situation of critical non-compliance.

A very important element of Metrology 4.0 is the communication of measuring and manufacturing elements, which is one of the key elements of the Industry 4.0 strategy. As in the case of technological devices, also every measuring device will be equipped with a system of sensors monitoring its condition on an ongoing basis and sending information about observed irregularities. These sensors will force periodic calibration, which in many cases will be carried out automatically (partly already today, in robotic measuring cells equipped with optical scanning systems). In addition, the measuring system will send information to the technological machine regarding tasks already completed and planned, as well as related to the observed irregularities. Due to this, the machining center will be able to automatically carry out corrective actions, ultimately ensuring the highest quality product. Such measuring devices will work in the production line, which is an increasingly common practice, naturally provided that the right conditions related to ambient temperature and gradients (per hour, per day and per meter) are provided. From this, it's only a step to construct technological and measuring machines, combining manufacturing and control capabilities. This concept requires a double frame inside the machine: one for machining and the other for measuring tasks. It is also necessary to provide climatic conditions and vibration isolation, however, ideas for this type of system may already appear in the near future.

Metrology 4.0 is also a philosophical change in the process of assessing the subject - no longer based on the dimensions alone, but the point cloud and its compliance with CAD data. Artificial intelligence will support the measuring process, including select bases and adjust measurement data to nominal. This procedure is partly carried out in measuring systems.

The new approach also characterizes the information-rich metrology. The idea for its introduction comes from the analysis of surface unevenness [7], but its application goes far beyond this framework. This idea consists in using not only the value of mesurand, but also the knowledge related to its determinants when determining the measurement results. It is said about correction of result due to thermal conditions, calibration data and data related to the instrument and the measured object. Already now, temperature correction is common in coordinate measuring machines, especially those with smaller maximum allowable errors.

\section{Measurements in incremental techniques}

These incremental techniques have prepared the basis for a new metrological approach [8]. It turned out that what was sufficient in relation to objects made by conventional techniques ceased to be appropriate. The specificity of additive processes requires a different approach.

On the micro scale, the simplest example is the separation of signal from the profilometer into waviness and roughness. In surfaces formed as a result of machining, this is of great importance, because waviness is due to machine tool problems (e.g. insufficient rigidity), and roughness - due to tool problems (shape and parameters of the cutting edge). Specifying and separating these two components and - as a consequence - analyzing each of them separately have a deep sense. For this purpose, a sampling length (cut-off) is used, which due to the mathematical justification for some new filtration techniques, has recently changed into a nesting index. In incremental techniques, it is possible to theoretically divide surface texture- e.g. for the most popular FDM techniques - into roughness (i.e. unevenness on the applied thread) and waviness (irregularities resulting from subsequent threads), but this is practically not justified. The situation is similar in the case of other additive 
manufacturing techniques [9]. An example image of the surface obtained with additive techniques is shown in Fig. 3.

In this approach, surface topography should either be assessed in aggregate, or - which is a much more common practice - functionally filtered. Filtering techniques for surface irregularities are rapidly developing. Currently, they offer users of measuring instruments many options for removing insignificant features, distorting the image of the surface, or highlighting important elements. In addition to already known Gaussian filters, these techniques include robust, wavelet, spline and morphological filters, implemented in various ways and with the help of various combinations [10]. Detailed descriptions of these filters are included in individual parts of the ISO 16610 standard.

An exemplary image of the surface from Fig. 3, after functional filtration, is shown in Fig. 4. A pronounced discontinuity around $6 \mathrm{~mm}$ towards the abscissa was reduced to a not very deep crack.

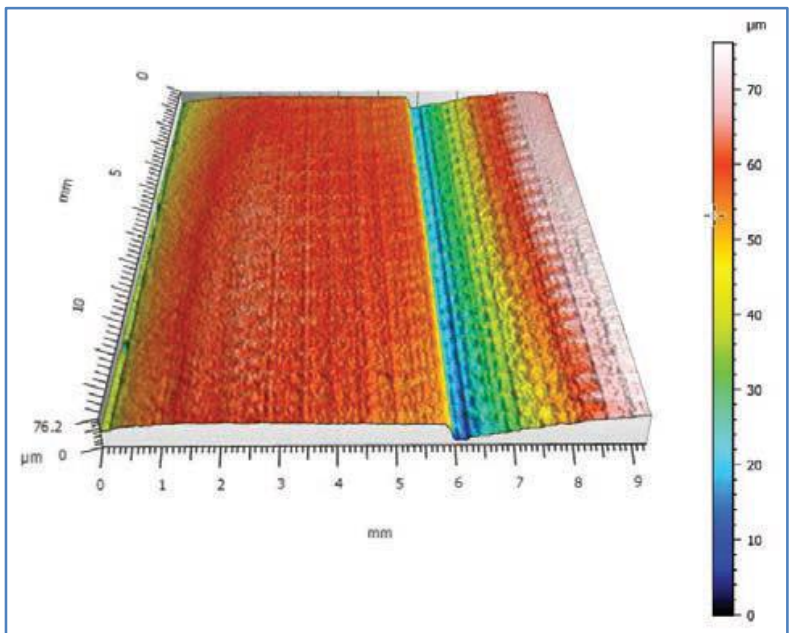

Fig. 3. Incremental surface area obtained with a CT scanner

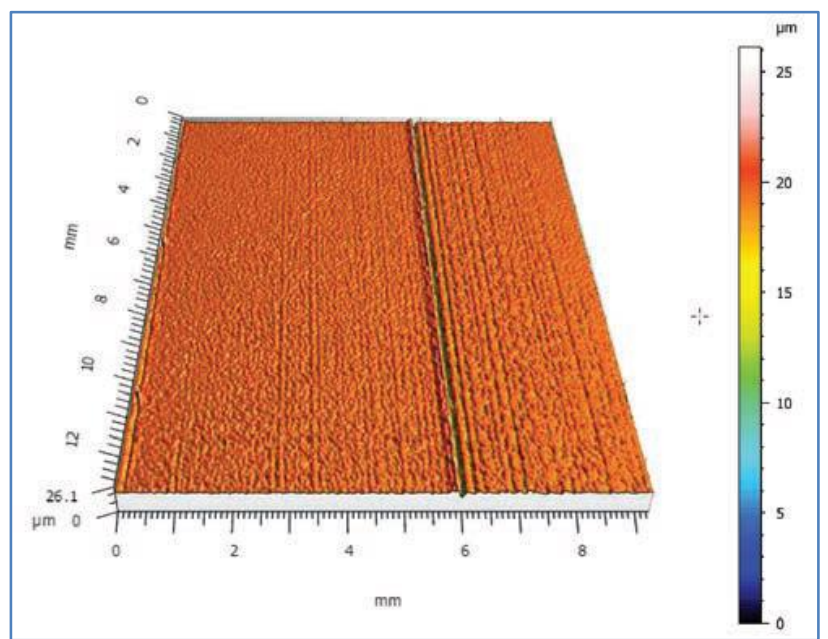

Fig. 4. Surface from Fig. 3 after functional filtration

Due to the specificity of filtration and surface features, measurements in incremental techniques are often used with meso scale instruments that offer the possibility of measuring surface topography (micro) and classic geometrical features (macro) [11]. Two techniques that stand out in a special way are focal differentiation microscopy [12] and scanning coherence interferometry. Surface topography measurements are thus combined with measurements of some geometric features. Due to very complicated internal shapes that can be obtained by incremental techniques, computed tomography, described in the next part of this article, is used for measurements.

\section{Coordinate measuring technique}

Coordinate measuring machines on a macro scale have been popular for many years and have become indispensable in various industries. At the same time, the coordinate measuring technique has improved significantly. Diversity, complicated shapes and measuring tasks have led to the development of optical measuring tools that allow the implementation of tasks difficult to perform by the contact method.

Scanning optical heads, used in coordinate measuring machines, enable fast non-contact measurement and obtaining more information than contact measuring heads. Over time, these heads developed into independent devices - 3D scanners. Their great advantage is the speed of collecting a huge amount of information about the measured product and readability of the presentation of results $[13,14]$. They are based on the principle of measuring the light reflected or scattered from the surface of the measured object.

There are structured light scanners and laser scanners. Structured light scanners use light projection of a specific structure, i.e. their projectors project patterns of e.g. gray codes, phase shifted fringes or other code forms (free shapes, circles, etc.) onto the measured surface. These are usually systems placed on tripods, but there are separate, stationary measuring machines, in which the measured object is inserted and the measurement is carried out in automatic mode (Fig. 5).

Such scanners implement the assumptions of Metrology 4.0 - they have handle for an object rotating about an axis to enable comprehensive measurement of geometrical features from all sides, and after enrichment with 
automatic calibration, they can cooperate with an external robot that provides subsequent objects for measurement. These types of systems are characterized by a constant component of the maximum allowable error at the level of several micrometers, which allows them to compete with coordinate measuring machines.

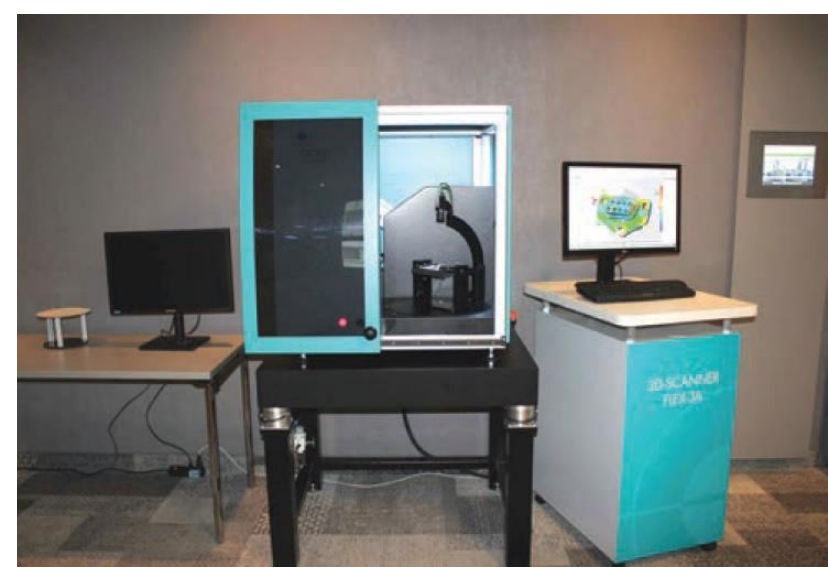

Fig. 5. Coordinate measuring scanner in the automatic station [15]

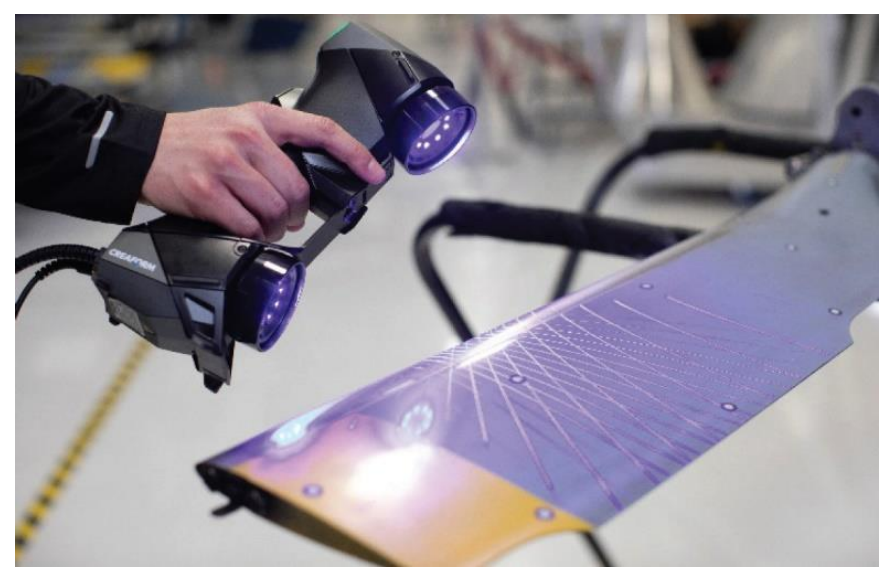

Fig. 6. Creaform 3D HandySCAN handheld laser scanner using blue light [16]

Structured light scanners are increasingly being replaced by newer solutions in many applications - laser scanners. They are smaller and enable hand-held measurement, therefore they replace scanners mounted on tripods, offering much better mobility and virtually zero sensitivity to external light. Initially, solutions based on laser action were known as laser scanning heads or laser triangulation heads placed on coordinate machines or measuring arms. Currently, they function as stand-alone laser scanners working in manual or automatic mode and have become one of the most common and effective methods of data acquisition (Fig. 6).

The principle of laser scanning heads is based a point, line or set of laser lines (in the latest solutions - up to 11 crosses) on the optical system emitting on the surface of the scanned object and observed by a CCD camera. In 2019, the red light used so far began to be replaced by blue light with much shorter wave. The effects of this are better resolution and improved accuracy parameters. Increasingly new optical and electronic solutions enable data collection at $60 \mathrm{~Hz}$ ( $60 \mathrm{frames} / \mathrm{sec}$ and acquisition of almost 500,000 points/sec). Such speed allows to avoid problems related to vibration and scanning of so-called free hand and real-time spatial data retrieval. This is a great help when scanning a complex object and a great advantage compared to structural light scanners.

Spatial scanning - resulting from the development of optical scanning techniques - is one of the key measurement processes in Metrology 4.0. The components of these techniques are: digitization based on large data sets, generation of color deviation maps and work on free surfaces, description of which is replaced by a cloud of points. The scanner can work with a cobot, i.e. a collaborative robot, due to which it implements the idea of metrology as close to production as possible (directly in the production line - in-line or in parallel with it - at-line). More advanced use of the scanning system is carried out for measuring purposes, where production robots are installed, with high setting and working speeds. Fig. 7 shows the scanner on the robot and the measuring cell.

This solution is an example of the automation of scanning in the concept of Metrology 4.0. The task is carried out in an independent measuring cell with a loading system. The scanner head works with a tracker that tracks its position continuously, which allows to work without additional markers, the application of which is tedious and time-consuming.

The system of laser light rays allows to simultaneously measure surfaces in different colors, absorbing and reflecting radiation, without the need for matting. The tracker guarantees better accuracy parameters due to automatic photogrammetry. In this way, the system provides so-called dynamic reference, due to which it can measure - also using angular motion - on an integrated rotary table. The operator's task is to program the measurement and launch the platform; further actions are carried out automatically, without his presence.

The cell has safeguards to prevent entry during measurement. The system is equipped with the option of automatic calibration using a special template and software module. An additional element that is part of the concept of Metrology 4.0, implemented in the ITA laboratory, is a camera system that allows for tracking the measurement process [18]. The observer, often located very far from the measuring system, receives a message with an access link. The cameras are mounted on the walls of the measuring cell or on the head of a robot moving with the measuring head. The observer verifies the measurement strategy on an ongoing basis, without moving 
from his workplace. Further level of interaction is the possibility of the observer's interference in the measurement process. It boils down, among others, to the actions taken by the observer at different levels of access, depending on metrological knowledge and knowledge of measurement software. Therefore, it cannot only make direct contact with the operator (via an Internet communicator) and jointly make decisions regarding the tested object, but also interrupt the measuring cycle independently, e.g. if the number of features exceeding the tolerance is too large. It can also run the measurement program itself for selected features, if it turns out that they cause the most problems in classifying the product as compliant with the specification, and modify the selected part of the measurement procedure. The implementation of this task is provided by an image transfer kit consisting of cameras and software with the option of switching views between them, allowing for interaction with a person supervising the measurement from a remote location.
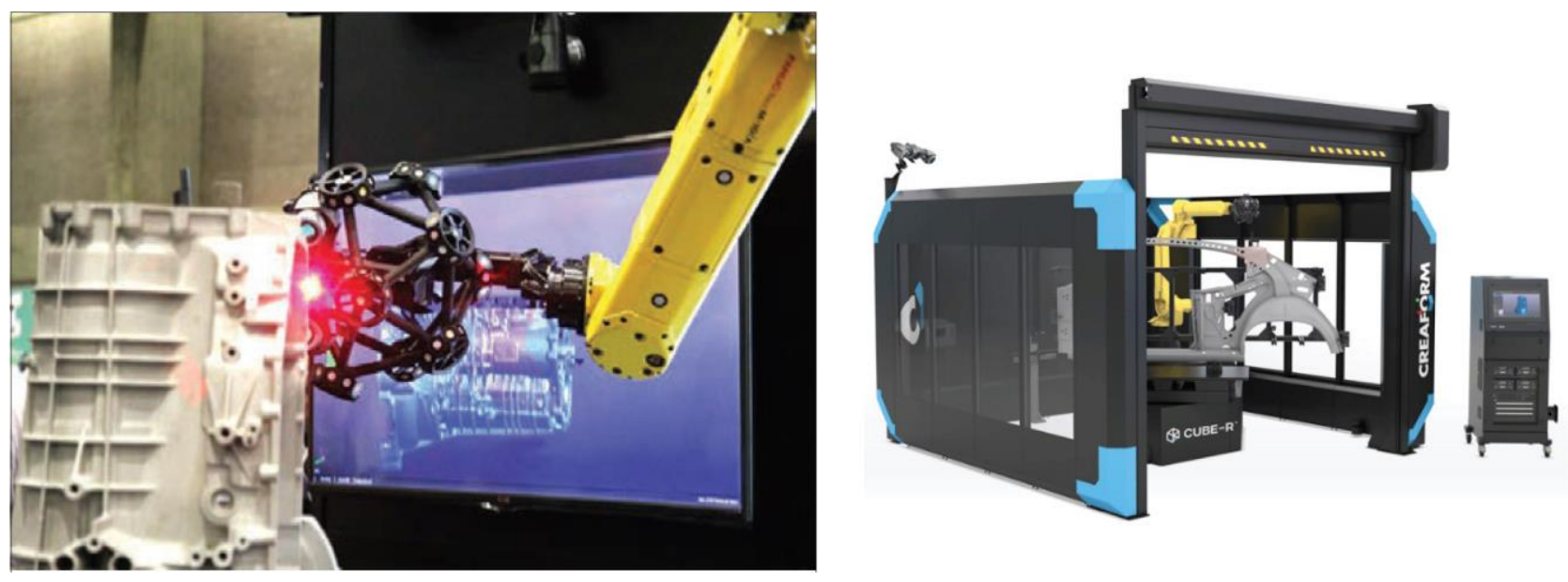

Fig. 7. Scanner on robot and measuring cell [17]

Electromagnetic radiation can be used in metrology not only in the visible range. Computed tomography, which is based on X-rays, is gradually making its way and is increasingly used to analyze not only defects, but also geometric features. A detailed description of this technique can be found in [19].

Tomographs used in medicine have parameters strictly matched to the tasks assigned to them. Due to the safety of the living organism, the radiation dose is reduced to a minimum and the measurement time is shortened. The best tomographs for medical applications have a resolution of $0.1 \mathrm{~mm}$, but most devices offer a resolution of up to $0.5 \mathrm{~mm}$ [20]. These values are suitable for imaging the human body, but in most cases, insufficient for laboratory or industrial research. Therefore technical tomographs are often called microtomographs - they allow for imaging with a resolution even below a micrometer. They are not intended for the study of living organisms, so they have longer exposure to X-rays (more pictures are taken, their recording time is longer) and higher X-ray tube power.

A lot of practical information on tomography in metrology appeared in recent years in Mechanik in the papers by Professor E. Ratajczyk [21-24]. Only a few specific aspects are worth discussing here.

Computed tomography in non-medical applications is such a new technique that in many cases it is difficult to talk about standard solutions. However, it can be assumed as a classic system, in which the measured object is on a rotary table, and the lamp and detector are stationary or perform a linear movement. There are also solutions with a motion system identical to medical tomographs. They are intended directly to work in the production line or to assess selected products in parallel with the production line. Their example can be a tomograph to control aluminum castings (among others, in the automotive industry), the concept of which is shown in Fig. 8.

Basic use of this tomograph is to control the thickness of the walls inside the castings. In the era of capacity reduction and power increase, this parameter is critical to the durability and life of engines. Due to the measurement speed of tens of millimeters per second and the inspection time of one piece of about 1 minute, such a device is suitable for use directly on (or at) the production line.

An important element in the characteristics of technical tomographs is image quality. Due to the specificity of $\mathrm{X}$-rays and phenomena occurring when it passes through the measured objects, the image is distorted by various artifacts. Good software preparing the output file for analysis should delete them. The most advanced is the scatter correct function developed by specialists from GE (Fig. 9 [26]). 


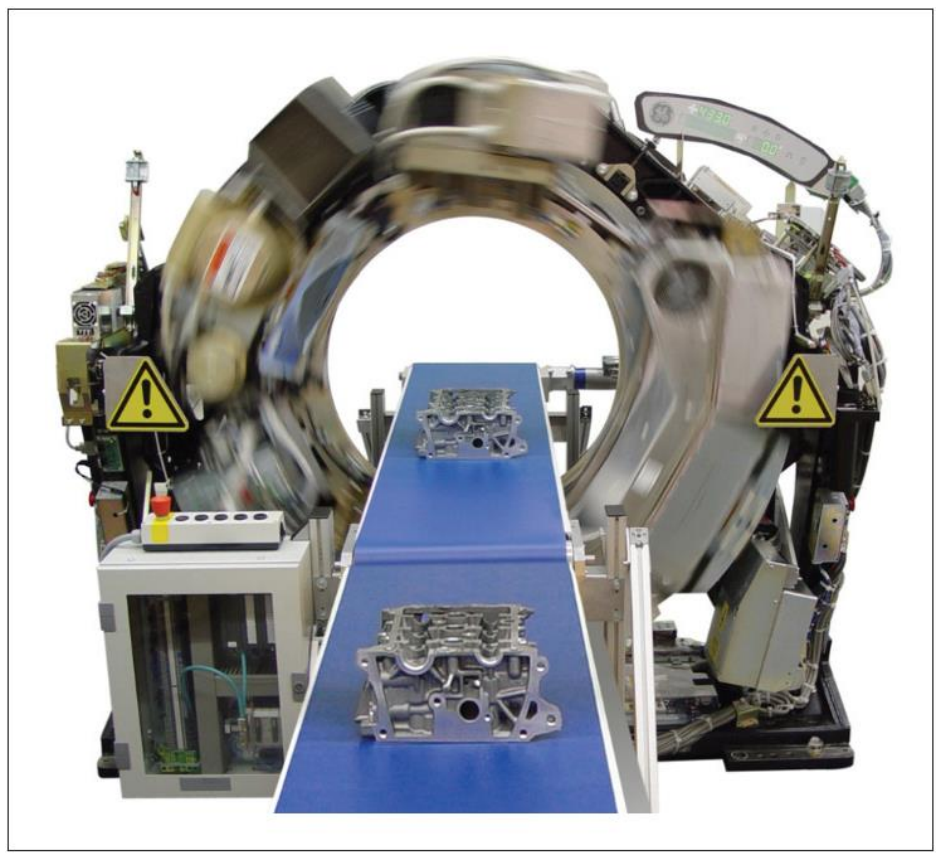

Fig. 8. Concept of the Speedscan CT [25]
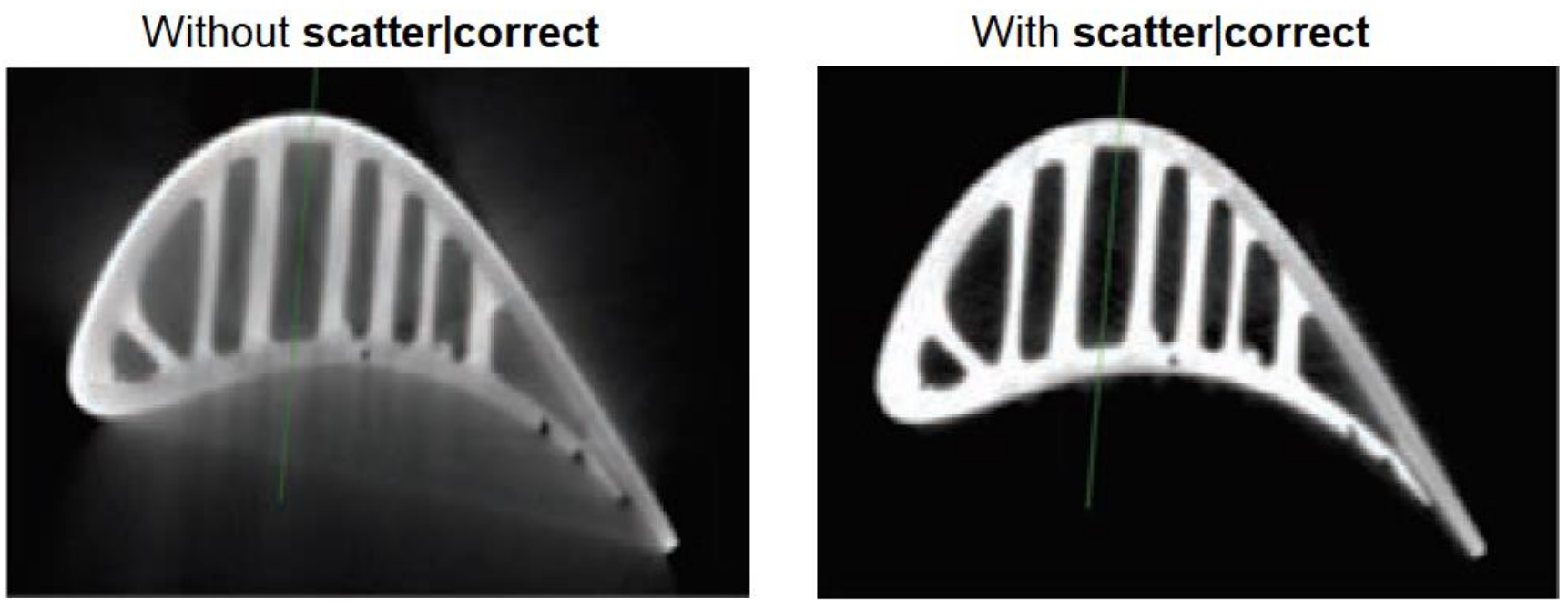

Fig. 9. Scatter correct function - improving image quality

In this way, a very good set of output data can be obtained, which is critical for the accuracy of the analysis of geometrical features and defects.

When tomographs are used, especially without precise control of temperature parameters, the question arises about thermal changes, which in the metrology of length and angle are the deciding factor for accuracy. An $\mathrm{X}$-ray tube is an important source of heat, and the greater the power, the greater its generation. Research carried out at the Department of Metrology and Measurement Systems of the Poznan University of Technology found that the temperature on the surface of the X-ray tube can exceed even $40^{\circ} \mathrm{C}$. Results of the sample analysis for the directional lamp are shown in Fig. 10.

Thus, is - because of the temperature - the uncertainty of measuring geometrical features using a tomograph so large that it discriminates against its use and the cooling system is not sufficient? The reality is more optimistic. In the case of low powers, after exceeding the set temperature, the cooling system is turned on, and then - when the cooling medium reaches a certain temperature - it is turned off. This is manifested by wavelike characteristics. In other cases, the anode temperature increases dynamically and is maintained at a higher level, which forces continuous operation of the cooling system.

In this case, tests on the temperature distribution as a function of distance from the front of the X-ray tube were also carried out. Results show that the temperature on the front surface of the lamp - in the place from 
which the X-rays are emitted - increases very clearly with increasing power, but at a distance from the lamp, this effect is not so strong.

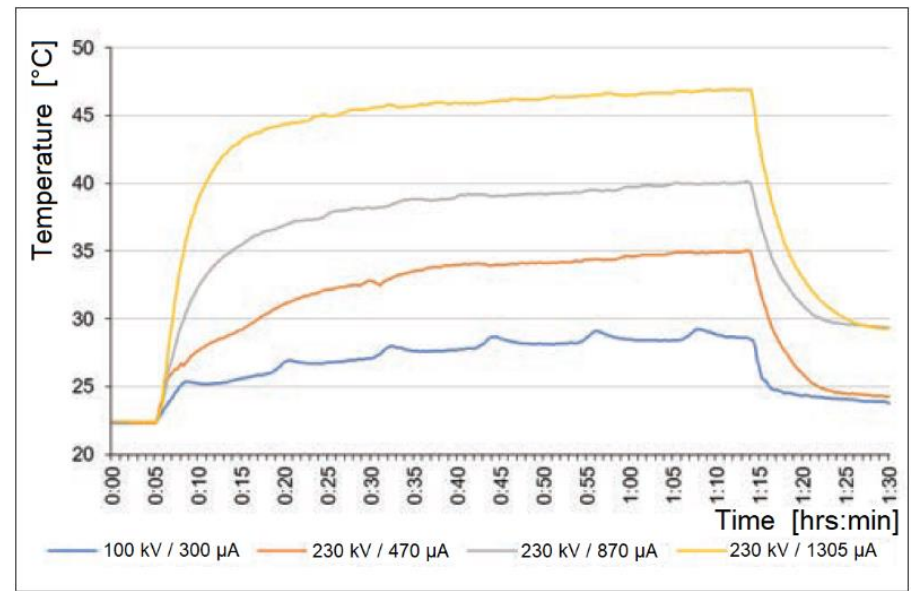

Fig. 10. Temperature distribution on the front surface of the directional lamp for different power outputs [19]

For $240 \mathrm{kV}$ and $1305 \mu \mathrm{A}$, or $300 \mathrm{~W}$, after an hour of work, the temperature at the head of the lamp increases by $24.5^{\circ} \mathrm{C}$, but at a distance of $15 \mathrm{~mm}$ from the forehead, this increase is only $4.6^{\circ} \mathrm{C}$, at $30 \mathrm{~mm}$ it is $3.1^{\circ} \mathrm{C}$, at a distance of $45 \mathrm{~mm}-2.3{ }^{\circ} \mathrm{C}, 60 \mathrm{~mm}-2.0^{\circ} \mathrm{C}, 150 \mathrm{~mm}-1.3^{\circ} \mathrm{C}$, while the tomograph chamber temperature increases by $0.7^{\circ} \mathrm{C}$. This is important information, because the use of high power X-ray tube increases the spot in the focus, which forces the reduction of geometric magnification by moving the measured object away from the radiation source to avoid blurring of the image. Thus, in this case, the impact of temperature changes, which are the result of radiating X-rays in the area where the element is located, is small.

\section{Summary}

Finally, it is worth mentioning the more formal side of length and angle metrology. The works of the ISO/TC 213 Technical Committee responsible for dimensional and geometrical specifications as well as verification of products have been ongoing since 1996. The committee has already developed 146 standards. The most important standardization works currently under way include the following parts of the standards: ISO 10360 (part 11 on computer tomographs and part 13 on optical scanners, previously included in part 8), ISO 25178 (regarding the spatial geometric structure of the surface), ISO 16610 (concerning filtration methods), ISO 21920 (regarding the analysis of surface unevenness based on the profile and including, among others: new drawing markings regarding surface texture, unevenness parameters calculated from the profile and measurement conditions), as well as standards related to tolerances and bases (ISO 5459, ISO 2692, ISO 8062, ISO 22081, etc.). These works show how important this part of activities is to harmonize requirements and specifications for science and industry. It is worth noting that one of the last meetings of the committee in September 2018 was organized in Poznań by the Department of Metrology and Measurement Systems of the Poznań University of Technology [28].

An important element of length and angle metrology is the creation and development of accredited calibration laboratories in accordance with ISO 17025 [27]. Using services of such laboratories guarantees that the calibration results are reliable and impartial. The Polish Center for Accreditation certificate, recognized in most technically significant countries in the world, confirms that the accredited entity:

- has competent staff,

- has certified standards and appropriate equipment for checking instruments,

- has knowledge about checking these instruments and has experience in the implementation of calibrations,

- uses reliable and correct methods of checking instruments.

The path presented in the article, followed by Metrology 4.0, indicates trends that have appeared in recent years. Whether it will be a bumpy road or rather a straight highway - they will show in the coming years. Nearby, because the number of years between successive industrial revolutions is getting smaller. It can therefore be expected that the fifth industrial revolution will appear in about 20 years. Then it will turn out how real and economically and functionally justified the assumptions of the fourth revolution that are being realized in front of our eyes. 


\section{REFERENCES}

[1] Wieczorowski M. „Digitalizacja powierzchni w aplikacjach mikro, mezo i makro”. Mechanik. 11 (2018): 944-949, https://doi.org/10.17814/mechanik.2018.11.166.

[2] „Raport. Rynek obróbki stali w Polsce”. Dodatek do czasopisma STAL Metale \& Nowe Technologie. Katowice: Elamed, 2018.

[3] Schwab K. „Czwarta rewolucja przemysłowa”. Warszawa: Studio EMKA, 2018, ISBN: 978-83-650-6881-1.

[4] Wieczorowski M. „Metrologiczne wyzwania strategii Przemysł 4.0”. VIII Kongres Metrologii. Augustów, 2019.

[5] Abbott E.J., Bousky S., Williamson D.E. “The profilometer". Mechanical Engineering. 60 (1938): 205-216.

[6] Hocken R.J., Pereira P.H. (eds.). "Coordinate Measuring Machines and Systems". Boca Raton: CRC Press, 2012. https://content.taylorfrancis.com/books/download?dac=C2009-0-24288-

7\&isbn=9781420017533\&format=googlePreviewPdf.

[7] Senin N., Leach R. "Information-rich surface metrology". Procedia CIRP. 75 (2018): 19-26, https://doi.org/10.1016/i.procir.2018.05.003.

[8] Leach R., Thompson A., Senin N. "A metrology horror story: the additive surface". Proceedings of ASPEN/ASPE 2017 Spring Topical Meeting on Manufacture and Metrology of Structured and Freeform Surfaces for Functional Applications. 14-17 March 2017, Hong Kong, China.

[9] Budzik G., Siemiński P. „Techniki przyrostowe. Druk 3D. Drukarki 3D”. Warszawa: WPW, 2015. ISBN: 978-83-7814255-3.

[10] Wieczorowski M. „Wykorzystanie analizy topograficznej w pomiarach nierówności powierzchni”. Rozprawa habilitacyjna, 429. Poznań: Wydawnictwo Politechniki Poznańskiej, 2009.

[11] Mathia T.G., Pawlus P., Wieczorowski M. „Recent trends in Surface metrology”. Wear. 271, 3-4 (2011): 494-508, https://doi.org/10.1016/j.wear.2010.06.001.

[12] Mendak M., Wieczorowski M., Grochalski K., Gapiński B. „Ocena nierówności powierzchni toczonej i zużycia ostrza z wykorzystaniem mikroskopu różnicowania ogniskowego". Mechanik. 8-9 (2018): 724-726, https://doi.org/10.17814/mechanik.2018.8-9.115.

[13] Wieczorowski M., Ruciński M., Koteras R. "Application of optical scanning for measurements of castings and cores". Archives of Foundry Engineering. 10 (2010): 265-268.

[14] Wieczorowski M., Koteras R., Znaniecki P. „Wykorzystanie skanera optycznego w kontroli jakości karoserii samochodu". PAK. 56/1 (2010): 40-41.

[15] "FLEX-3A". Materiały firmy Jenoptik Otto.

[16] "Handy Scan Blue Elite". Materiały firmy Creaform.

[17] “CubeR". Materiały firmy Creaform.

[18] Wieczorowski M., Szelewski M., Matuszak M., Pollak K. „Platforma do interakcyjnych analiz metrologicznych $w$ koncepcji Przemysł 4.0 umożliwiająca zrobotyzowanq laserowq digitalizację powierzchni $w$ skali makro". Projekt RPWP.01.05.02-30-0065/18.

[19] Gapiński B. „Obrazowanie i pomiary w technicznej tomografii komputerowej ze szczególnym uwzględnieniem przedmiotów wykonanych technikami przyrostowymi i analizy nierówności powierzchni". Poznań: Wydawnictwo Studio Poligrafia, 2019, ISBN 978-83-953889-0-3.

[20] Carmignato S., Pierobon A., Savio E. "First International Intercomparison of Computed Tomography Systems for

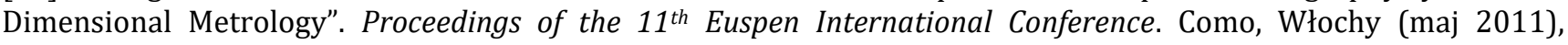
www.euspen.eu/knowledge-base/ICE11114.pdf.

[21] Ratajczyk E. „Tomografia komputerowa CT w zastosowaniach przemysłowych. Cz. I. Idea pomiarów, główne zespoły i ich funkcje". Mechanik. 2 (2011): 112-117.

[22] Ratajczyk E. „Tomografia komputerowa CT w zastosowaniach przemysłowych. Cz. II. Tomografy i ich parametry, przykłady zastosowań". Mechanik. 3 (2011): 226-231.

[23] Ratajczyk E. „Tomografia komputerowa CT w zastosowaniach przemysłowych. Cz. III. Tomografy i ich parametry, przykłady zastosowań". Mechanik. 4 (2011): 326-331.

[24] Ratajczyk E. „Tomografia komputerowa CT w zastosowaniach przemysłowych. Cz. IV. Oprogramowania, parametry dokładności i metody ich wyznaczania". Mechanik. 5-6 (2011): 474-479.

[25] "Speedscan". Materiały firmy GE Baker Hughes.

[26] "Scater correct". Materiały firmy GE Baker Hughes.

[27] Wieczorowski M., Gapiński B., Humienny Z., Falińska K. „Co nowego w metrologii współrzędnościowej i tolerowaniu. Z działalności Komitetu Technicznego ISO/TC 213”. Mechanik. 4 (2019): 268-269.

[28] Gruszka J., Wieczorowski M., Śmierzchalska B., Szelewski M., Zachwiej I., Śmierzchalski D. „Laboratorium Wzorcujące ITA". Mechanik. 5-6 (2018): 430-433, https://doi.org/10.17814/mechanik.2018.5-6.53. 